\title{
ALTERNATIF MODEL PEMIDANAAN TINDAK PIDANA PORNOGRAFI SIBER
}

\author{
${ }^{1)}$ Faizin Sulistio \\ ${ }^{2)}$ Nazura Abdul Manap \\ ${ }^{1)}$ Universitas Brawijaya Malang, Jl. MT. Haryono 169 Malang \\ Email: faizin@ub.ac.id \\ ${ }^{2)}$ Universiti Kebangsaan Malaysia, Bangi Selangor Malaysia \\ Email: nazura@ukm.edu.my
}

Diterima: 29 Desember 2016 | Direview: 6 Januari 2017 | Disetujui: 18 Januari 2017

\begin{abstract}
This study was conducted to examine the alternative punishment for the cyber pornography crime. The purpose of this study is to find the punishment formulation which theoretically and philosophically is more acceptable in accordance with the moral development of society and technology. This normative juridical study uses a conceptual approach. While the analysts is conducted by descriptive method to find the basic theory of punishment for the crime of cyber pornography. The results can be concluded that imprisonment has not provided solutions in the criminal offense of cyber pornography without accompanied by other alternative punishment. The alternatives are special minimum penalties, social work, restrictions on access to electronic devices (internet) and compensation to victims of pornography.
\end{abstract}

Key words: cyber pornography, imprisonment, criminal alternative

\begin{abstract}
Abstrak
Kajian ini dilakukan untuk mengkaji alternatif pidana yang tepat untuk tindak pidana pornografi siber. Tujuan kajian ini menemukan formulasi pemidanaan yang secara teoritikal dan filosofis lebih dapat diterima sesuai dengan perkembangan moral masyarakat dan tekhnologi. Kajian bersifat Yuridis Normatif ini menggunakan pendekatan konseptual. Sedangkan analis dilakukan dengan metode deskriptif analisis untuk mencari dasar teori pemidanaan untuk tindak pidana pornografi siber. Hasil yang dapat disimpulkan dalam kajian ini adalah pidana penjara belum memberi solusi dalam pemidanaan tindak pidana pornografi siber tanpa dibarengi dengan alternatif pidana yang lain. Alternatif pidana itu antara lain denda dengan minimum khusus, kerja sosial, pembatasan akses terhadap perangkat elektronik (internet) dan ganti rugi kepada korban pornografi.
\end{abstract}

Kata kunci: pornografi siber, penjara, alternatif pidana

\section{Latar Belakang}

Penggunaan upaya hukum termasuk hukum pidana, sebagai salah satu upaya mengatasi masalah sosial termasuk dalam bidang kebijakan penegakan hukum. Disamping itu karena tujuannya adalah untuk mencapai kesejahteraan masyarakat pada umumnya, maka kebijakan penegakan hukum 
itupun termasuk dalam bidang kebijakan sosial, yaitu segala usaha yang rasional untuk mencapai kesejahteraan masyarakat. Sebagai suatu masalah yang termasuk kebijakan, maka penggunaan (hukum) pidana sebenarnya tidak merupakan suatu keharusan. Untuk mengakomodasi kebutuhan dan aspirasi masyarakatnya tersebut, negara Indonesia telah menentukan kebijakan sosial (social policy) yang berupa kebijakan untuk mewujudkan kesejahteraan sosial (social welfare policy) dan kebijakan memberikan perlindungan sosial (social defence policy). ${ }^{1}$

Kebijakanuntukmemberikanperlindungan sosial (social defence policy) salah satunya dengan upaya-upaya pencegahan dan penanggulangan tindak pidana atau kejahatan yang aktual maupun potensial terjadi. Segala upaya untuk mencegah dan menanggulangi tindak pidana/kejahatan ini termasuk dalam wilayah kebijakan kriminal (criminal policy) dengan menggunakan sarana hukum pidana (penal) dan oleh karena itu termasuk bagian dari kebijakan hukum pidana (penal policy). ${ }^{2}$

Upaya untuk menanggulangi semua bentuk kejahatan senantiasa terus diupayakan, kebijakan hukum pidana yang ditempuh selama ini tidak lain merupakan langkah yang terus menerus digali dan dikaji agar upaya penanggulangan kejahatan tersebut mampu mengantisipasi secara maksimal tindak pidana yang secara faktual terus meningkat. Penggunaan hukum pidana sebagai sarana untuk melindungi masyarakat dari ancaman maupun gangguan kejahatan sebenarnya merupakan masalah politik kriminal yaitu usaha rasional untuk menanggulangi kejahatan.

Sudarto mengatakan ada beberapa hal yang dapat digunakan sebagai kriteria apakah suatu perbuatan dapat diberi suatu ancaman pidana atau tidak. Hal-hal tersebut adalah:

a. Penggunaan hukum pidana harus berusaha mewujudkan masyarakat adil makmur yang merata materiil dan spirituil berdasarkan Pancasila dalam wadah Negara Kesatuan Republik Indonesia. Hukum pidana bertujuan untuk menanggulangi kejahatan dan sekaligus tindakan penanggulangan itu sendiri.

b. Perbuatan yang hendak dikehendaki yaitu yang mendatangkan kerugian baik bagi masyarakat maupun bagi diri sendiri pelakunya.

c. Usaha mencegah suatu perbuatan dengan mempergunakan sarana hukum pidana, perlu disertai dengan perhitungan biaya yang harus dikeluarkan dan hasil yang diharapkan akan dicapai (cost and benefit principle).

d. Pembuatan peraturan hukum pidana perlu memperhatikan kemampuan daya kerja dari badan-badan penegak hukum (over be lasting), yang justru akan mengakibatkan efek dari suatu peraturan itu menjadi berkurang. ${ }^{3}$

1 Barda Nawawi Arief, Masalah Penegakan Hukum dan Kebijakan Penanggulangan Kejahatan, (Bandung: Citra Aditya Bakti, 2001), hlm. 73.

2 Barda Nawawi Arief, Kapita Selekta Hukum Pidana, (Bandung: Citra Aditya Bakti, 2003), hlm. 240.

3 Sudarto, Hukum dan Hukum Pidana, (Bandung: Alumni, 1983), hlm. 144. 
Isu pornografi ${ }^{4}$ merupakan bagian yang tidak terpisah dari perkembangan peradaban manusia melalui kerja-kerja seni kuno zaman purba. ${ }^{5}$ Namun, perkembangan internet membuat pornografi berkembang dengan pesat. ${ }^{6}$ Bahkan pornografi merupakan satu industri yang bernilai jutaan dollar Amerika dengan pengedaran dan penyebaran yang sangat cepat ke seluruh dunia. ${ }^{7}$ Di Amerika Serikat, industri ini melebihi industri sepak bola, bola basket dan baseball yang di jadikan satu kumpulan. ${ }^{8}$ Begitu pula dengan di negara Itali yang yang mengalami peningkatan jumlah tapak web yang mengandung bahan pornografi anak sebesar 93\% pada tahun 2002 dan 2004. Terkadang pornografi anak dalam suatu tapak web menjadi bagian dari pada pornografi dewasa. Hal ini terjadi kerana dalam tapak web pornografi menyediakan beberapa kategori pornografi seperti: Amateurs, Asian, Babes, BigTits, Cumshots, Ebony, Gay, Group, Hardcore, Interracial, Lesbians, Mature, Movies, Shemales, Teens. ${ }^{9}$

Sayangnya Pengaturan mengenai pornografi sangat lokalitas dan dipengaruhi oleh nilai-nilai budaya bangsa yang bersangkutan. Hal ini bahkan terjadi pada pengaturan pornografi anak, seperti pada perbuatan melihat dan memiliki bahan bermuatan pornografi anak yang pengaturan diberbagai negara berbeda. Indonesia bahkan tidak secara spesifik mengatur pada perbuatan melihat dan memiliki pornografi anak, padahal di negara yang lain perbuatan ini dianggap tercela dan merupakan tindak pidana. Dari uraian latar belakang diatas maka penulis mencoba membuat tulisan dengan mendasarkan pada kesesuaian pidana penjara pada tindak pidana pornografi siber dan alternatif pemidanaan yang lain yang lebih sesuai dengan perkembangan masyarakat dan teknologi. Tulisan ini lebih berorientasi pada pendekatan kebijakan perundangundangan khususnya dalam menetapkan dan merumuskan pemidanaan, sehingga menggunakan pendekatan yuridis normatif yang bertumpu pada bahan-bahan hukum.

\section{Pembahasan}

Diskursus mengenai Pornografi sebagai bentuk perbuatan yang menyimpang sangat dipengaruhi oleh nilai-nilai moral yang diakui oleh suatu masyarakat. Oleh itu konsep pornografi yang terbentukpun sangat

4 Elena Martellozzo dan Hellen Taylor, "Cycle of Abuse”, Index on Cencorship Vol. 38, Issue 1, (March 2009): 117.

5 S. Ost, Child Pornography and Sexual Grooming: Legal and Societal Responses, (Cambridge: Cambridge University Press, 2009), p. 25.

6 M. Taylor and E. Quayle, Child Pornography: An Internet Crime, (London: Routledge, 2003), pp. 159-163.

7 Cristina Cattaneo dkk, "Can facial proportions taken from images be of use for ageing in cases of suspected child pornography? A pilot study", Int J Legal Med Vol. 126, Issue 1, (January 2012): 139.

8 Martin S. Weinberg dkk, "Pornography, Normalization, and Empowerment", Arch Sex Behav Vol. 39, Issue 6, (December 2010): 1389.

9 Jonathan James McCradie Lillie, “Cyberporn, Sexuality and The Net Apparatus", Convergence Vol. 10, Issue 1, (March 2004): 47. 
dipengaruhi rasa lokalitas yang biasanya terkait erat dengan rasa kesusilaan dalam masyarakat.Di negara liberal yang sangat menjunjung tinggi kebebasan individu, aktivitas pornografibukanlah sebuah perbuatan yang merugikan kepentingan publik sehingga tidak perlu dikriminalisasi sebagai perbuatan pidana. Kalaupun terjadi kriminalisasi biasanya terkait dengan pornografi anak yang konsepnya bukan semata-mata pada moralitas melainkan perlindungan kepada anak. Hal inilah yang menjadi satu ciri khas pembeda dalam proses kriminalisasi pornografi di Indonesia dibandingkan dengan negara lain (barat). Pornografi di Indonesia lebih menekankan pada relasi antara moralitas dalam masyarakat dengan hukum. Jadi dapat dikatakan konteks pornografi dibatasi oleh aturan-aturan pengendali sosial lain seperti hukum adat dan agama. Di Indonesia kriminalisasi pornografi dapat kita lihat dalam pasal 282 KUHP dan pasal 1 (1) Undangundang No 44 tahun 2008 tentang Pornografi. Dalam pasal 282 KUHP diuraikan beberapa larangan yang terkait dengan aktivitas terkait dengan pornigrafi, yaitu:

a. Menyiarkan, mempertunjukkan atau menempelkan dengan terang-terangan tulisan, gambar atau benda yang melanggar kesusilaan

b. Membuat, memasukkan ke dalam negara, mengirim langsung kedalam negara, meneruskan mengeluarkannya ke luar negara, atau menyediakan tulisan, gambar atau benda yang melanggar kesusilaan untuk disiarkan, dipertunjukkan atau ditempelkan secara terang-terangan.

c. secara terang-terangan atau dengan sengaja menyiarkan suatu tulisan, menawarkan tulisan dengan tidak diminta atau menunjukkan, bahawa tulisan, gambar atau benda yang melanggar kesusilaan itu dapat diperoleh.

Uraian yang terdapat dalam KUHP yang kemudian dikenali sebagai bentuk-bentuk pornografi di jabarkan lebih detil dalam pasal 1 (1) UU No 44 tahun 2008, yaitu:

"Pornografi adalah gambar, sketsa, ilustrasi, foto, tulisan, suara, bunyi, gambar bergerak, animasi, kartun, percakapan, gerak tubuh, atau bentuk pesan lainnya melalui berbagai bentuk media komunikasi dan/atau pertunjukan di muka umum, yang memuat kecabulan atau eksploitasi seksual yang melanggar norma kesusilaan dalam masyarakat"

Perkembangan definisi pornografi seperti dalam pasal diatas merupakan sebuah usaha yang menjadi konsen sosial untuk menyelaraskan perkembangan teknologi dengan bentuk-bentuk baru aktivitas pornografi.

Aktivitas di Internet tidak lepas dari perbuatan manusia dan akibat hukum di dalam kehidupan nyata (real life/physical world). Pemikiran ini memunculkan beberapa konsep perlunya pengaturan hukum yang dapat mengakomodasi berbagai kepentingan manusia, baik para pengguna internet sebagai subjek yang melakukan aktivitas atau perbuatan-perbuatan dalam maupun orang 
yang terkena dampak dari aktivitas manusia tadi di dunia nyata. Permasalahn pengaturan ini sering dikaitkan dengan eksistensi hukum konvensional dalam menjangkau dan mengatur aktivitas di internet yang mempunyai karakteristik yang khas dan melampau batasan ruang dan waktu yang dibangun dalam hukum konvensional.

Pro kontra pengaturan ini biasanya berpijak pada pendapat bahwa karakteristik aktivitas di internet yang bersifat lintas batas, menyebabkan aktivitas tersebut tidak tunduk pada batasan-batasan teritorial. Selain itu hukum konvensional yang bertumpu pada batasan-batasan teritorial juga tidak mampu untuk menyelesaikan persoalan hukum yang timbul dari aktivitas-aktivitas lintas batas dan waktu di internet.

Menurut Mieke ada dua model yang dapat diadopsi untuk mengatur aktivitas-aktivitas di ruang siber, yaitu:

a. Model Ketentuan payung (Umbrella Provision)

Model ketentuan payung hukum digunakan untuk memberikan upaya harmonisasi hukum. Dengan model ini ada masterpiece yang akan memandu peraturan yang lebih spesifik. Dalam model ini dapat memuat hal-hal berikut, yaitu:

1. Materi-materi pokok yang perlu diatur;

2. Keterkaitan hubungan antara undangundang yang telah ada dengan undangundang yang akan datang agar tercipta hubungan sinergis.

\section{b. Model Triangle Regulation}

Model ini menitikberatkan kepada hal-hal yang menjadi prioritas yang perlu diatur dalam peraturan perundang-undangan. Model perundang-undangan ini akan memilih prioritas kebutuhan yang mendesak dan harus segera diatur oleh hukum negara dengan tetap memperhatikan keselarasan peraturan perundang-undangan yang akan dibentuk dengan undang-undang yang telah ada.

Selain model perundang-undangan yang dibentuk, substansi perundangan yang akan diaturpun harus memuat model penyelesaian atau penanggulangan terhadap kejahatan pornografi, khususnya pornografi siber.

\section{A. Teori-Teori Pemidanaan}

Teori-teori yang berkaitan dengan pemidanaan berkembang mengikuti perubahan masyarakat. Hal ini merupakan reaksi dari berkembangnya kejahatan yang mewarnai kehidupan sosial masyarakat dari masa ke masa. Beberapa teori tujuan pemidanaan berkembang dalam ilmu hukum pidana yaitu teori absolut (retributif), teori relatif (deterrence/utilitarian), teori penggabungan (integratif), teori treatment dan teori perlindungan sosial (social defence). Teoriteori pemidanaan ini mempertimbangkan berbagai aspek sasaran yang hendak dicapai di dalam penjatuhan pidana. ${ }^{10}$

10 Dwidja Priyanto, Sistem Pelaksanaan Pidana Penjara Di Indonesia, (Bandung: Rafika Aditama, 2009), hlm. 22. 


\section{Teori retributif (absolut)}

Teori retributif dikenal juga sebagai teori absolut. Teori ini berpandangan bahwa pemidanaan merupakan pembalasan atas kesalahan yang telah dilakukan. Orientasi teori ini merujuk pada perbuatan dan kejahatan itu sendiri. Pemidanaan diberikan karena si pelaku harus menerima sanksi itu demi kesalahannya. Menurut teori ini, landasan hukuman terletak pada kejahatan itu sendiri. Hal ini karena kejahatan itu telah menimbulkan penderitaan bagi orang lain. Oleh karena itu sebagai imbalannya (vergelding) si pelaku harus diberi penderitaan. Teori ini secata tegas menyatakan bahwa setiap kejahatan harus diikuti dengan hukuman, tidak boleh tidak, tanpa tawar menawar. Jadi, Seseorang mendapat pidana karena telah melakukan kejahatan. Tidak dilihat akibat-akibat apapun yang timbul dengan dijatuhkannya pidana, tidak peduli apakah masyarakat mungkin akan dirugikan. Pembalasan sebagai alasan untuk memidana suatu kejahatan. Penjatuhan pidana pada dasarnya penderitaan pada penjahat dibenarkan karena penjahat telah membuat penderitaan bagi orang lain. Menurut Hegel bahwa, pidana merupakan keharusan logis sebagai konsekuensi dari adanya kejahatan.

Karakteristik yang dibangun oleh teori retributif, yaitu:

1. Tujuan pidana adalah semata-mata untuk pembalasan;

2. Pembalasan adalah tujuan utama dan di dalamnya tidak mengandung saranasarana untuk tujuan lain misalnya untuk kesejahteraan masyarakat;

3. Kesalahan merupakan satu-satunya syarat untuk adanya pidana;

4. Pidana harus disesuaikan dengan kesalahan si pelanggar;

5. Pidana melihat ke belakang, ia merupakan pencelaan yang murni dan tujuannya tidak untuk memperbaiki, mendidik atau memasyarakatkan kembali si pelanggar.

\section{Teori pencegahan/detterence theory (teori relatif)}

Teori relatif sering dipersamakan dengan teori pencegahan (deterrence). Teori ini berpandangan bahwa pemidanaan bukan bentuk pembalasan atas kesalahan si pelaku, tetapi sebagai sarana mencapai tujuan bermanfaat untuk melindungi masyarakat menuju kesejahteraan. Teori ini kemudian memunculkan tujuan pemidanaan sebagai sarana pencegahan, yaitu pencegahan umum yang ditujukan pada masyarakat. Berdasarkan teori ini, hukuman yang dijatuhkan untuk melaksanakan maksud atau tujuan dari hukuman itu, yakni memperbaiki ketidakpuasan masyarakat sebagai akibat kejahatan itu. Tujuan hukuman harus dipandang secara ideal, selain dari itu, tujuan hukuman adalah untuk mencegah (prevensi) kejahatan.

Menurut Leonard, teori relatif pemidanaan bertujuan mencegah dan mengurangi kejahatan. Pidana harus dimaksudkan untuk mengubah tingkah laku penjahat dan orang lain yang berpotensi atau cederung melakukan kejahatan. Tujuan pidana adalah tertib 
masyarakat, dan untuk menegakan tata tertib masyarakat itu diperlukan pidana.

Pidana bukanlah sekedar untuk melakukan pembalasan atau pengimbalan kepada orang yang telah melakukan suatu tindak pidana, tetapi mempunyai tujuan-tujuan tertentu yang bermanfaat. Pembalasan itu sendiri tidak mempunyai nilai, tetapi hanya sebagai sarana untuk melindungi kepentingan masyarakat. Dasar pembenaran pidana terletak pada tujuannya adalah untuk mengurangi frekuensi kejahatan. Pidana dijatuhkan bukan karena orang membuat kejahatan, melainkan supaya orang jangan melakukan kejahatan. Sehingga teori ini sering juga disebut teori tujuan (utilitarian theory).

Karakteristik teori relatif (utilitarian), yaitu:

1. Tujuan pidana adalah pencegahan (prevention);

2. Pencegahan bukan tujuan akhir tetapi hanya sebagai sarana untuk mencapai tujuan yang lebih tinggi yaitu kesejahteraan masyarakat;

3. Hanya pelanggaran-pelanggaran hukum yang dapat dipersalahkan kepada si pelaku saja (misal karena sengaja atau culpa) yang memenuhi syarat untuk adanya pidana;

4. Pidana harus ditetapkan berdasar tujuannya sebagai alat untuk pencegahan kejahatan;

5. Pidana melihat ke muka (bersifat prospektif), pidana dapat mengandung unsur pencelaan, tetapi unsur pembalasan tidak dapat diterima apabila tidak membantu pencegahan kejahatan untuk kepentingan kesejahteraan masyarakat.

\section{B. Pidana Penjara Tepatkah Untuk Pornografi Siber?}

Pidana penjara merupakan pidana utama diantara pidana yang menghilangkan kemerdekaan seseorang. Jenis pidana ini dapat dijatuhkan untuk seumur hidup atau untuk sementara waktu. Berbeda dengan jenis pidana lainnya, maka pidana penjara ini adalah suatu pidana berupa pembatasan kebebasan bergerak dari seorang terpidana. Pidana ini dilakukan dengan menutup akses keluar terpidana di dalam sebuah lembaga pemasyarakatan. Didalam Lembaga pemasyarakatan seorang terpidana wajib menaati semua peraturan tata tertib yang telah diprogramkan. Selain hilangnya kemerdekaan, terpidana pidana penjara juga kehilangan hak-hak tertentu, seperti hak memilih dan dipilih, hakim memangku jabatan publik, dan beberapa hak sipil lain. ${ }^{11}$

Lama pidana penjara sementara minimal 1 hari dan maksimum 15 tahun dan untuk tindak pidana tertentu sampai 20 tahun. Roeslan Saleh menjelaskan bahwa banyak para pakar memiliki keberatan terhadap penjara seumur hidup ini, keberatan ini disebabkan karena dengan putusan demikian terhukum tidak akan mempunyai harapan lagi kembali dalam masyarakat. Padahal harapan tersebut dapat dipulihkan oleh lembaga grasi, dan lembaga remisi. $^{12}$ 
Sebagai bentuk hukuman yang sudah umum diterapkan di seluruh dunia, namun dalam perkembangan terakhir ini banyak yang mempersoalkan kembali manfaat penggunaan pidana penjara. Di samping masalah efektivitas,juga sering dipermasalahkan akibat-akibat negatif dari pidana penjara. Puncak dari kritik-kritik tajam terhadap keberadaan pidana penjara tersebut yakni dengan adanya gerakan untuk menghapus pidana penjara. ${ }^{13}$ Sebagai contoh kritikan peenggunaan pidana penjara dalam jangka waktu yang pendek. Pidana ini yang biasanya paling lama 6 bulan dianggap mempunyai dampak yang negatif bagi narapidana. Padahal pidana jangka waktu pendek biasa diterapkan pada kejahatan yang dianggap kejahatan yang tidak serius atau tidak mempunyai dampak yang terlalu berbahaya. Sebagai contoh pengenaan pidana pada pelaku pornografi di Indonesia yang tidak melibatkan pornografi anak biasanya hanya berkisar 5 bulanan. Padahal dalam era pornografi siber, kasus pornografi bukan menurun akan tetapi semakin tinggi dengan jenis kasus dan modus yang bervariasi. Bahkan sebagian besar pelaku masih berstatus pelajar atau mahasiswa yang melakukan kesalahan mengedarkan gambar atau video pornografi dengan berbagai modus yang mengiringi. Oleh karena itu penggunaan pidana penjara tanpa sebuah alternatif pidana yang lain kurang memberi pilihan yang tepat sesuai dengan kasus yang terjadi. Jarang terjadi pula hakim menerapkan pidana penjara pendek tersebut dengan menggunakan alternatif lembaga pidana bersyarat dan pelepasan bersyarat. Padahal KUHP memberikan peluang kepada hakim daripada sekedar memenjarakan seseorang.

Roeslan Saleh menyatakan tentang pidana bersyarat sebagai berikut:

"Apabila hakim menjatuhkan pidana penjara paling lama satu atau kurungan, tetapi tidak termasuk kurungan pengganti, maka dalam putusannya dapat memerintahkan pula bahwa pidana tidak usah dijalani kecuali jika dikemudian hari ada putusan hakim yang menentukan lain, disebabkan karena terhukum melakukan suatu perbuatan pidana sebelum masa percobaan yang ditentukan dalam perintah tersebut di atas habis atau karena terhukum selama masa percobaan tidak memenuhi syarat khusus yang mungkin ditentukan dalam perintah itu. Inilah yang disebut pidana bersyarat. Jadi pidana bersyarat dapat diadakan bila mana hakim menjatuhkan pidana penjara paling lama satu tahun. Yang menentukan bukanlah pidana yang diancamkan atas delik yang dilakukan melainkan pidana yang dijatuhkan". ${ }^{14}$

Sementara pelepasan bersyarat dapat dilakukan jika terhukum telah menjalani duapertiga dari lamanya pidana penjara yang dijatuhkan kepadanya, yang sekurangkurangnya adalah sembilan bulan. Maka kepadanya dapat diberikan pelepasan

13 Barda Nawawi Arief, Kebijakan Legislatif dalam Penanggulangan Kejahatan dengan Pidana Penjara, (Yogyakarta: Genta Publishing, 2010), hlm. 43.

14 Roeslan Saleh, Stelsel Pidana Indonesia, (Jakarta: Aksara Baru, 1978), hlm. 64. 
bersyarat, dan jika terhukum harus menjalani beberapa pidana berturut-turut maka pidana itu dianggap sebagai satu pidana.

Dalam hal ini Roeslan Saleh menerangkan dalam tulisannya, bahwa:

"Untuk memberikan penglepasan bersyarat juga ditentukan suatu masa percobaan, serta syarat-syarat yang harus dipenuhi selama masa percobaan. Masa percobaan itu lamanya sama dengan sisa waktu pidana penjara yang belum dijalani ditambah satu tahun. Jika terhukum ada dalam tahanan maka waktu itu tidak termasuk masa percobaan. Inilah yang disebut penglepasan bersyarat, yaitu yang bagian akhir dari pidana tidak dijalankan. Penglepasan bersyarat ini tidak dapat diberikan terhadap mereka yang dijatuhkan pidana penjara seumur hidup. Tentunya terkecuali bila mana pidana penjara seumur hidup tersebut dengan grasi diubah menjadi pidana penjara sementara waktu, dan kemudian dilakukan penglepasan bersyarat. Penglepasan bersyarat juga tidak mungkin diberikan terhadap mereka yang dikenakan pidana kurungan". ${ }^{15}$

Beberapa kritik-kritik berkenaan dengan pidana penjara jangka pendek ini dikemukakan oleh Wolf Middendorf ${ }^{16}$ yang mengemukakan bahwa pidana penjara pendek (misal 6 bulan ke bawah) tidak mempunyai reputasi baik, tetapi pada umumnya diyakini lebih baik dan tidak dapat dihindarkan. Di kebanyakan negara dijatuhkan dalam perkara lalu lintas, khususnya pada kasus-kasus mengendarai kendaraan dalam keadaan mabuk.
Menurut beliau narapidana pidana jangka pendek ini dalam penerapannya harus dipisah dari napi pidana penjara yang dipidana dengan waktu yang lama. Bahkan narapidana dengan pidana jangka waktu pendek seharusnya dikirim ke “open camp' dimana mereka dipekerjakan untuk keuntungan masyarakat. Pengiriman pada tempat tertentu dan bekerja untuk kepentingan masyarakat sebetulnya alternatif yang lebih tepat dan menghindarkan dari stigma negatif terpidana penjara. Pakar hukum Johannes Andenaes dalam bukunya berjudul "Punishment and Deterrence" menyatakan bahwa "...Pidana jangka waktu pendek seperti itu tidak memberikan kemungkinan untuk merehabilitasi si pelanggar, tetapi malah akan mencap dia dengan stigma penjara dan membuat kontakkontak yang tidak menyenangkan. Kelemahan pidana ini adalah :

a. Tidak membantu/menunjang secara efektif fungsi membuat tidak mampu ("it does not effectively serve an incapacitative function") dan;

b. Sebagai suatu pencegahan umum, ia lebih rendah mutunya dari pada pidana lama ("as a general deterrent it is inferior to longer sentences")

c. tidak keberatan untuk mempertahankan pidana penjara pendek sebagai tulang punggung dari sistem pidana apabila denda dan probation dipandang tidak cukup. Pidana denda dan probation diharapkan dapat menggantikan pidana penjara berdasarkan pertimbangan humanistis dan ekonomis." 
Selain itu, S.R. Brody menyatakan bahwa lamanya waktu yang dijalani di dalam penjara, tampaknya tidak berpengaruh pada adanya penghukuman kembali (reconviction). Tidak ada bukti bahwa pidana penjara dengan waktu yang lama, membawa hasil yang lebih baik dari pada penjara pendek.

Pernyataan senada juga dinyatakan oleh Sir Rupert Cross menyatakan bahwa ada alasan yang bersifat humanistis untuk memastikan bahwa pidana penjara pendek memang sesuai dengan kebutuhan untuk mencegah si pelanggar dan membuat penghargaan bagi sasaran lain dari penjara yaitu meminimalkan penderitaan si pelanggar dan keluarganya serta keinginan untuk memperbaiki napi dengan mengurangi kepadatan lembaga pemasyarakatan.

Walaubagaimanapun pada bagian lain beliau tidak setuju dengan pendapat bahwa pidana penjara waktu pendek tidak efektif sebagai sarana pencegahan individu alasannya karena banyak orang dipidana penjara untuk pertama kali tidak kembali lagi ke penjara, berdasarkan hasil penelitian jumlahnya sekitar 75\%. Dari jumlah itu diperkirakan kebanyakan dijatuhi pidana penjara 6 bulan atau kurang.

Oleh itu sanksi penjara jangka waktu pendek atau "Short term incarceration" dapat menjadi sanksi efektif, tetapi hanya terbatas pada beberapa persyaratan, yaitu dalam keadaan khusus, untuk tipe-tipe pelanggar tertentu dan ketika digunakan sebagai langkah awal dalam proses resosialisasi.
Dengan adanya kelemahan-kelemahan dalam pidana penjara jangka pendek tersebut, maka isu pidana penjara jangka waktu pendek tersebut telah menimbulkan kecenderungan internasional yang sangat eksklusif dalam dekade terakhir ini.

Pakar hukum pidana Muladi menyatakan bahwa saat ini sudah berkembang konsep untuk selalu mencari alternatif dari pidana kemerdekaan (alternatif to imprisonment) dalam bentuknya sebagai sanksi alternatif (alternatif sanctions). Alasan sebenarnya tidak hanya bersifat kemanusiaan, tetapi juga atas dasar pertimbangan filosofis pemidanaan dan alasan-alasan ekonomi. Oleh karena itu, Konsep Rancangan KUHP juga berusaha mencari sanksi alternatif, tanpa harus menghilangkan pidana penjara dalam bentuk pidana tutupan, pidana pengawasan, pidana denda dan pidana kerja sosial. ${ }^{17}$

Hanya disayangkan, sampai saat ini pidana penjara merupakan pilihan utama dalam rejim pidana modern dan dianggap paling baik. Walaupun diakui kurang memberikan efek jera untuk tindak pidana tertentu. Akibatnya hakim tidak leluasa untuk memeberi alternatif pidana yang sesuai dan memberi efek jera maupun rehabilitatif kepada pelaku.Hal ini dapat kita lihat pada rumusan jenis pidana pokok dalam Rancangan KUHP tidak jauh berbeda dengan KUHP atau UU Pornografi. Perbedaan hanya ditambahkannya pidana kerja sosial yang selama ini tidak dikenal dalam KUHP. 


\section{Alternatif Pemidanaan Tindak Pidana Pornografi}

Menurut Phillips dalam bukuya A First Book English Law, sebagaimana dikutip oleh Andi Hamzah, yang dipandang sebagai tujuan pemidanaan yang berlaku sekarang ialah variasi dari bentuk-bentuk penjeraan (detterent), baik ditujukan kepada pelanggaran hukum itu sendiri maupun kepada mereka yang mempunyai potensi menjadi penjahat, perlindungan kepada masyarakat dari perbuatan jahat, perbaikan (reformasi) kepada penjahat. Hal tersebut terakhir yang paling modern dan populer dewasa ini, bukan saja bertujuan memperbaiki kondisi pemenjaraan tetapi juga mencari alternatif lain yang bukan bersifat pidana dalam membina pelanggar hukum. ${ }^{18}$

Pertanyaan yang sering dimunculkan para pakar hukum pidana dalam berbagai seminar adalah pertanyaan tentang bagaimana hukum pidana sebaiknya atau seharusnya pada masa ini dan masa yang akan datang. Pertanyaan ini berkaitan dengan bidang politik hukum pidana (penal policy), yaitu bagaimana sebaiknya hukum pidana itu dibuat, disusun dan digunakan untuk mengatur atau mengendalikan tingkah laku manusia dalam masyarakat. khususnya guna menanggulangi kejahatan yang dilakukan baik oleh anggota masyarakat maupun oleh penguasa.

Upaya-upaya untuk mencari alternatif sanksi dari pidana perampasan kemerdekaan jangka pendek ini juga didukung oleh Perserikatan Bangsa-Bangsa (PBB). Dalam Kongres ke-2 PBB mengenai "The Prevention of Crime and Treatment of Ofenders" tahun 1960 di London merekomendasikan bahwa prakteknya penghapusan menyeluruh pidana penjara jangka pendek tidaklah mungkin. pemecahannya yang realistis hanya dapat dicapai dengan mengurangi jumlah penggunaanya. Pengurangan berangsurangsur itu dengan meningkatkan bentukbentuk pengganti/alternatif (pidana bersyarat, pengawasan/probation, denda, pekerjaan di luar lembaga. dan tindakan-tindakan lain yang tidak mengandung perampasan kemerdekaan.

Pertanggungjawaban pidana serta sanksi pidana itu sendiri merupakan suatu masalah pokok dalam hukum pidana. Sudarto mengatakan ada beberapa hal yang dapat digunakan sebagai kriteria apakah suatu perbuatan dapat diberi suatu ancaman pidana atau tidak. Hal-hal tersebut adalah:

a. Penggunaan hukum pidana harus berusaha mewujudkan masyarakat adil makmur yang merata materiil dan spirituil berdasarkan Pancasila dalam wadah Negara Kesatuan Republik Indonesia. Hukum pidana bertujuan untuk menanggulangi kejahatan dan sekaligus pengugeran terhadap tindakan penanggulangan itu sendiri.

b. Perbuatan yang hendak dikehendaki yaitu yang mendatangkan kerugian baik

18 Andi Hamzah, Sistem Pidana dan Pemidanaan Indonesia dari Retribusi ke Reformasi, Cetakan Ke-1, (Jakarta: Pradnya Paramita, 1986), hlm. 16. 
bagi masyarakat maupun bagi diri sendiri pelakunya.

c. Usaha mencegah suatu perbuatan dengan mempergunakan sarana hukum pidana, perlu disertai dengan perhitungan biaya yang harus dikeluarkan dan hasil yang diharapkan akan dicapai (cost and benefit principle).

d. Pembuatan peraturan hukum pidana perlu memperhatikan kemampuan daya kerja dari badan-badan penegak hukum (over be lasting), yang justru akan mengakibatkan efek dari suatu peraturan itu menjadi berkurang. ${ }^{19}$

Romli Atmasasmita menyatakan bahwa Perserikatan Bangsa-Bangsa memberikan perhatian yang cukup besar pada bangsabangsa di dunia dalam upaya penanggulangan kejahatan. Masalah sistem peradilan pidana dan penanggulangan kejahatan juga tidak luput dari perhatiannya. Perserikatan BangsaBangsa memandang masalah sebagai bagian dari masalah yang lebih luas dan kompleks sifatnya yaitu masalah sosial, ekonomi, budaya dan politik. ${ }^{20}$

Kejahatanmerupakan prilakumenyimpang yang akan senantiasa ada dan melekat pada setiap bentuk masyarakat. Kejahatan merupakan masalah sosial yang paling tua oleh sebab itu harus ditanggulangi. Dilihat dari akibatnya kejahatan dapat menganggu atau merusak dan merintangi tercapainya tujuan nasional dan juga mencegah penggunaan optimal dari sumber-sumber nasional Sudarto menyatakan bahwa penggunaan sarana penal dalam menanggulangi kejahatan tidak dapat dilepaskan keterkaitannya dengan kebijakan hukum pidana atau politik hukum pidana (criminal law policy). Sehubungan dengan hal tersebut, maka Soedarto mengemukakan bahwa melaksanakan politik hukum pidana berarti mengadakan penilaian dan pemilihan untuk mencapai hasil perundang-undangan pidana yang paling baik, dalam arti memenuhi syarat keadilan dan daya guna. ${ }^{21}$

A Mulder, menyatakan bahwa politik hukum pidana atau strafrechts politiek ialah garis kebijakan untuk menentukan:

1. Seberapa jauh ketentuan-ketentuan pidana yang berlaku perlu diubah atau diperbaharui.

2. Apa yang dapat diperbuat untuk mencegah terjadinya tindak pidana.

3. Cara bagaimana penyidikan, penuntutan, peradilan dan pelaksanaan pidana harus dilaksanakan. ${ }^{22}$

Dilihat dari sudut "criminal policy", upaya penanggulangan kejahatan (termasuk penanggulangan pornografi siber) tentunya tidak dapat dilakukan secara parsial dengan hukum pidana (sarana penal), tetapi harus ditempuh pula dengan pendekatan integral/ sistemik. Sebagai salah satu bentuk dari hitech crime, adalah wajar upaya penanggulangan 
pornografi siber juga harus ditempuh dengan pendekatan teknologi (techno prevention). Di samping itu diperlukan pula pendekatan budaya/kultural, pendekatan moral/edukatif (terlebih untuk delik kesusilaan), dan bahkan pendekatan global (kerja sama internasional) karena pornografi siber dapat melampaui batas-batas negara (bersifat "transnational/ transborder").

Oleh itu, perlu satu sistem pemidanaan yang mempertimbangkan pelaku tindak pidana dan perbuatan yang dilakukan. Terhadap korporasi sebagai pelaku tindak pidana maka perlu pemberatan yang sesuai dengan entitas korporasi sebagai badan hukum. Bentuk model pidana yang sesuai antara lain denda minimum khusus dan ganti rugi kepada korban. Sedangkan terhadap orang sebagai pelaku tindak pornografi siber, selain denda dan ganti kerugian perlu hukuman alternatif yang lain yang bersifat rehabilitatif seperti kerja sosial dan pembatasan terhadap koneksi yang berhubungan dengan internet.

\section{Denda dan Pedoman Pemidanaan Denda Minimum Khusus}

Sistem minimum khusus ataupun jenis alternatif pidana yang lain dapat dilakukan dengan merujuk ketentuan pasal 103 KUHP, yaitu selama undang-undang diluar KUHP mengatur secara khusus tentang ketentuan tata cara atau pedoman pemidanaan. Pidana denda dengan minimum khusus dilakukan terhadap perbuatan yang dianggap sangat berbahaya ataupun pelaku yang mempunyai karakteristik khusus seperti korporasi.

Dalam formulasinya penetapan jumlah denda dapat dirumuskan hanya kategori dendanya saja sehingga mudah disesuaikan dengan perkembangan situasi. Hal ini mengingat pidana denda berbeda dengan jenis tindak pidana pokok lainnya merupakan jenis pidana yang yang bernilai uang dan mempunyai nilai ekonomi. Dengan demikian pidana denda mudah berubah nilainya, karena pengaruh perkembangan moneter maupun perkembangan ekonomi suatu masyarakat baik dilihat secara nasional maupun internasional. ${ }^{23}$

Dengan demikian jelas, bahwa ancaman minimum khusus ini tidak diancamkan pada setiap jenis tindak pidana, tetapi diancamkan pada jenis tindak pidana yang dipandang menimbulkan disparitas pidana dan membahayakan atau sangat merugikan masyarakat yang diperberat oleh akibatnya. Permasalahan yang sering terjadi adalah beberapa peraturan perundang-undangan yang memuat ancaman atau formulasi pidana denda dengan sistem minimal khusus maupun dalam jumlah yang cukup besar. Sementara tidak diatur dengan detail tatacara atau pedoman pemidanaan. Baik itu tata cara pembayaran dengan tunai dan kapan batas akhir dari pembayaran. Konsekuensi apa saja yang bisa dijatuhkan apabila jumlah denda yang dibayarkan tidak sesuai dengan jumlah yang ditetapkan atau dikenakan. Dalam

23 Barda Nawawi Arif dan Muladi, Teori-teori dan Kebijakan Pidana, (Bandung: Citra Aditya Bakti, 1992), hlm. 182. 
tindak pidana pornografi siber jenis denda ini sangat cocok diterapkan pada korporasi yang membuka usaha pornografi siber.

\section{E. Pidana Ganti Kerugian Kepada Korban}

Pidana Ganti kerugian, merupakan suatu pidana yang mewajibkan seseorang yang telah bertindak merugikan orang lain untuk membayar sejumlah uang ataupun barang pada orang yang dirugikan. Dalam perkembangan peraturan perundang-undangan di Indonesia, pidana ganti kerugian tidak hanya menjadi domain dari hukum perdata, tetapi juga telah masuk ke dalam hukum Pidana. Perkembangan ini terjadi karena semakin meningkatnya perhatian masyarakat dunia terhadap akses korban tindak pidana dalam sistem peradilan pidana.

Ketentuan pidana Ganti kerugian dapat ditelusuri dalam hukum berbagai hukum adat di Indonesia. Baik dalam hukum Adat yang tidak tertulis, maupun dalam ketentuanketentuan yang tertulis. Sebagai contoh pada zaman kerajaan Majapahit terdapat kitab adigama atau agama yang memuat pidana ganti kerugian sebagai bentuk pidana pokok. Kitab ini memiliki pidana Ganti Kerugian dengan nama Panglicawa, Putukucawa dan Pamidara, demikian pula dalam pidana tambahannya dikenal sanksi berupa uang pembeli obat yang disebut Patibajampi atau Patuku tamba. Pidana Ganti Kerugian ini dibebankan pada tindak pidana pencurian, tatayi dan dusta yang menimbulkan korban, kelalaian yang menyebabkan matinya orang, pembunuhan terhadap orang yang tidak berdosa, merusak milik orang lain dan sebagainya. Sedangkan pidana tambahan berupa uang pembeli obat dibebankan pada pelaku jika pihak korban menderita luka-luka. ${ }^{24}$

Pidana Ganti kerugian dalam perspektif hukum adat merupakan suatu kewajiban yang harus dibayar karena adanya tuntutan dari pihak yang telah dirugikan. Tujuannya agar masalah yang terjadi dapat diselesaikan dengan damai. Selain itu, terdapat pidana Ganti Kerugian untuk mengadakan selamatan desa yang bertujuan untuk mengembalikan keseimbangan masyarakat.

Dalam hukum adat, selain Ganti Kerugian materiil dikenal pula Ganti kerugain yang immaterial, seperti paksaan menikah pada gadis yang telah dicemarkan. ${ }^{25}$ Fakta dari hukum adat diatas telah menunjukkan bahwa hukum Indonesia sejak jaman dahulu telah mengenal pidana Ganti kerugian, yang harus dibayar oleh orang yang telah melakukan perbuatan yang dipandang tercela oleh masyarakat kepada korban (orang yang menderita ataupun keluarga korban). Ganti kerugian ini dilakukan agar terciptanya perdamaian kembali ataupun agar keseimbangan masyarakat pulih kembali.

Keberadaan KUHP yang merupakan 
warisan Belanda yang dibentuk pada abad ke-19, tidak mengenal pidana Ganti Kerugian. Hal ini dikarenakan paradigma pada masa pembentukannya lebih kepada pembalasan (restributif). Walaupun demikian KUHP dalam ketentuan pidana Bersyarat, pada Pasal 14 c menyatakan bahwa hakim dalam menjatuhkan pidana bersyarat terhadap pelaku tindak pidana selain menentukan syarat umum dapat pula sekaligus menjatuhkan syarat khusus berupa ganti kerugian yang harus dipenuhi sebelum masa percobaannya berakhir, jadi tergesernya posisi hukum Adat oleh KUHP, telah menjauhkan kemungkinan korban-korban kejahatan di Indonesia untuk memperoleh ganti-kerugian.

Terlepas dari KUHP, sebenarnya dalam hukum Pidana positif yang lain ketentuan tentang Ganti kerugian juga dikenal. Undangundang Tindak Pidana Korupsi dalam Pasal 34 , mengatur tentang pidana tambahan berupa pembayaran uang pengganti yang jumlahnya sebanyak-banyaknya sama dengan harta benda yang diperoleh dari korupsi. Dalam hal ini ganti kerugian diberikan pada negara, karena negara adalah merupakan korban (collective victim). Dalam konteks pornografi siber maka sanksi ganti rugi ini juga dapat berupa korban kolektif yang diwakili negara dan penggunaannya untuk rehabilitasi mental korban pornografi. Selain itu, ganti kerugian juga dapat diberikan kepada orang yang secara langsung menjadi korban pornografi siber.

Sanksi Ganti Kerugian sebagaimana telah dinyatakan di atas, adalah berusaha untuk melindungi korban tindak pidana. Tetapi selain itu masih ada beberapa manfaat lain yang memberikan nilai lebih pada sanksi Ganti Kerugian bila dimasukkan ke dalam KUHP (Baru). Perlindungan terhadap korban kejahatan menjadi focus perhatian masyarakat dunia sekarang ini. Ada dua cara yang berkembang dewasa ini, yaitu Prosedural Rights Model dan Service Model. Model yang pertama menghendaki diikutsertakannya korban dalam proses peradilan, baik terlibat langsung dalam sidang pengadilan ataupun dibelakang sidang diberikan ikut mempertimbangkan sanksi yang akan dijatuhkan pada pelaku tindak pidana. Sedangkan model yang kedua adalah melayani korban tindak pidana, dengan menghilangkan atau mengurangi penderitaan korban.

Model yang kedua ini biasanya menggunakan ganti rugi sebagai sarana. Dari dua cara tersebut nampaknya Service Model lebih tepat untuk dilaksanakan, karena Prosedural Rights Model akan sangat menghambat kelancaran proses peradilan yang dikehendaki yaitu cepat tepat adil dan biaya ringan. Sebaliknya dengan menerima Service Model maka harus memasukkan sanksi Ganti Kerugian ke dalam hukum Pidana. Dengan demikian jika sanksi Ganti Kerugian nantinya menjadi bagian KUHP, maka hukum Pidana Indonesia akan diterima oleh dunia internasional. Disamping itu akan diterima oleh dunia internasional. Disamping itu akan 
menunjukan bahwa KUHP bersifat modern, karena telah memperhatikan perbuatan, pelaku dan korban (daad-dader straftrecht dan victim). Dalam menjatuhkan pidana pada seseorang tentu harus dipertimbangkan pula tujuan pemidanaan. Ada banyak tujuan Pidana yang dikenal. Tetapi konsep Rancangan Undang-undang Hukum Pidana (Baru) dalam Pasal 47 menentukan tujuan pemidanaan adalah untuk:

1. mencapai dilakukan tindak pidana dengan menegakkan norma hukum demi pengayoman masyarakat.

2. memasyarakatkan terpidana dengan mengadakan pembinaan sehingga menjadikan orang yang baik dan berguna;

3. menyelesaikan konflik yang ditimbulkan oleh tindak pidana, memulihkan keseimbangan, dan memdatangkan rasa damai dalam masyarakat;

4. membebaskan rasa bersalah pada terpidana.

Melihat keempat tujuan ini maka Sanksi ganti kerugian jelas memiliki tujuan yang lebih dekat pada upaya penyelesaian konflik dan membebaskan rasa bersalah pada terpidana. Sanksi Ganti Kerugian memang dari sejarah keberadaannya ditujukan untuk menyelesaikan konflik. Adanya ganti kerugian maka akan dianggap bahwa suatu peristiwa tidak pernah terjadi. Dengan demikian akan mengembalikan system kepercayaan korban dalam menghadapi kehidupan. Demikian pula akan membebaskan rasa bersalah terpidana yang dapat membuatnya tertekan dan justru berbahaya serta dapat merugikan dirinya atau masyarakat. Disamping itu secara psicologis dengan diterimanya uang ganti kerugian tersebut oleh korban berarti korban dapat dikatakan telah memberikan maaf pada pelaku tindak pidana tersebut. Jadi sanksi Ganti Kerugian sangat berperan sebagai jembatan perdamaian. Mengdindarkan pelaku kejahatan dari sanksi pokok yang berat dan menghindarkan negara mengeluardana lebih banyak untuk menanggulang kejahatan.

\section{F. Pembatasan Akses ke Perangkat Komputer}

Pembatasan kebebasan menggunakan alat-alat yang berhubungan dengan internet dikembangkan sebagai bentuk hukuman kepada pelaku yang melakukan pornografi siber. Model hukuman ini dikembangkan karena negara menyadari bahwa ada kekhususan tersendiri pada pelaku tindak pidana di alam siber. Pelaku merupakan orang yang mempunyai kelebihan khusus dalam bidang siber. Oleh karena itu beberapa negara seperti di Amerika Serikat, Inggris dan Wales mencoba menerapkan model pemidanaan ini. Biasanya, hukuman kepada pelaku yang berhubungan dengan internet dibagi dalam 3 (tiga) model, yaitu:

1. Pembatan penggunaan internet atau peralatan komputer yang mampu menghubungkan ke internet.

2. Pembatasan yang memerlukan penggunaan perangkat lunak monitoring.

3. Perangkat yang membutuhkan akses oleh 
mereka yang berkuasa pada peralatan yang digunakan oleh pelaku.

Tiga bentuk model ini akan digunakan sehingga dapat menyesuaikan pembatasan individu untuk pelaku.

\section{G. Hukuman Kerja Sosial}

Gagasan untuk menerapkan hukuman kerja sosial bagi pelaku tindak pidana dimaksudkan untuk memunculkan rasa malu, dan pada akhirnya menimbulkan efek jera. Hukuman kerja sosial juga diharapkan dapat memutus rantai konflik antara pelaku dengan korban. Sejumlah negara, seperti Belanda dan Inggris, memang mengenal jenis hukuman kerja sosial. KUHP Belanda versi 1996 pada judul punishment tercantum jenis hukuman community services. Pasal 22 ayat (1) huruf c KUHP Belanda versi bahasa Inggris mencantumkan rumusan berikut. The judge may only impose a penalty of community service upon request from the eccused to perform such work.

Menurut Romli Atmasasmita, hukuman kerja sosial lebih sering dipakai untuk tindak pidana kategori ringan. Konsep itu pula yang kemudian dianut RUU KUHP. Draf RUU KUHP versi 2015 misalnya mengenal hukuman kerja sosial sebagai pengganti pidana penjara yang tidak lebih dari enam bulan.

Penerapan hukuman kerja sosial yang meniru konsep hukuman kerja sosial seperti yang dikenal di Belanda dan Inggris lebih tepat diterapkan dalam kasus pornografi siber dengan kategori perbuatan yang ringan. Misalnya mengupload video atau gambar sendiri ke internet.

Beberapa alternatif hukuman terhadap tindak pidana pornografi siber pada dasarnya ada pertimbangan nilai yaitu keseimbangan antara nilai dari hasil perbuatan yang dikenakan pidana dengan biaya yang dikeluarkan. Sehubungan dengan hal ini maka tetap mempertahankan hukum dan hukum pidana dilihat dari sudut politik kriminal dan dari sudut tujuan, fungsi dan pengaruh dari hukum pidana itu sendiri, dengan istilah "masih adanya dasar susila dari hukum pidana". ${ }^{26}$

Penggunaan upaya hukum, termasuk hukum pidana, sebagai salah satu upaya untuk mengatasi masalah sosial termasuk dalam bidang kebijakan penegakkan hukum. Disamping itu karena tujuannya adalah untuk mencapai kesejahteraan masyarakat pada umumnya, maka kebijakan penegakkan hukum itupun termasuk dalam bidang kebijakan sosial, yaitu segala usaha yang rasional untuk mencapai kesejahteraan masyarakat. Sebagai suatu masalah yang termasuk masalah kebijakan, maka penggunaan (hukum) pidana sebenarnya tidak merupakan suatu keharusan. ${ }^{27}$

H.L. Packer dalam bukunya "The Limits of Criminal Sanction", sebagaimana dikemukakan oleh Muladi dan Barda Nawawi 


\section{Arief:}

a. Sanksi pidana sangatlah diperlukan; kita tidak dapat hidup, sekarang maupun di masa yang akan datang, tanpa pidana (the criminal sanction is indispensable; we could not, now or in the oreseeable future, get along without it).

b. Sanksi pidana merupakan alat atau sarana terbaik yang tersedia, yang kita miliki untuk menghadapi kejahatan-kejahatan atau bahaya besar dan segera serta untuk menghadapi ancaman-ancaman dari bahaya (the criminal sanction is the best available device we have for dealing with gross and immediate harms and threats of harm).

c. Sanksi pidana suatu ketika merupakan penjamin yang utama/terbaik dan suatu ketika merupakan pengancam yang utama dari kebebasan manusia. Ia merupakan penjamin apabila digunakan secara hemat cermat dan secara manusiawi; ia merupakan pengancam apabila digunakan secara sembarangan dan secara paksa (the criminal sanction is atau once prime guarantor and prime threatener of human freedom. Used providently and humanely, it is guarantor; used indiscriminately and coercively, it is threatener). ${ }^{28}$

\section{Simpulan}

Bertolak dari perumusan masalah dan pembahasan maka dapat ditarik beberapa kesimpulan, sebagai berikut:

1. Pidana Penjara merupakan model pidana modern yang dilandasi filosofi penjeraan kepada pelaku maupun masyarakat. Pidana penjara ini sampai saat ini belum tergantikan dalam memberikan hukuman yang memberi efek jera. Namun, disadari pula pidana penjara mempunyai beberapa kelemahan sehingga perlu pidana alternatif yang dapat memberikan efek jera, rehabilitatif maupun memulihkan keadaan akibat perbuatan pidana yang terjadi.

2. Alternatif model pemidanaan yang sesuai dengan arus utama filosofi pemidaan sekarang adalah model yang memadukan penjeraan, rehabilitatif dan pemulihan. Pemidanaan dalam model ini memilah pemidanaan selaras dengan berbahanya perbuatan yang dilakukan dengan mempertimbangkan pula aspek pelaku tindak pidana. Alternatif pemidanaan ini antara lain pidana kerja sosial, ganti kerugian, denda minimum khusus dan pembatasan akses ke capaian internet. 


\section{DAFTAR PUSTAKA}

Buku

Arief, Barda Nawawi dan Muladi. Teori-teori dan Kebijakan Pidana. Bandung: Citra Aditya Bakti, 1992.

. Kapita Selekta Hukum

Pidana. Bandung: Citra Aditya Bakti, 2003.

- Masalah Penegakan

Hukum dan Kebijakan Penanggulangan

Kejahatan. Bandung: Citra Aditya Bakti, 2001.

Atmasasmita, Romli. Sistem Peradilan Pidana

(Criminal Justice Sistem). Bandung:

Bina Cipta, 1996.

Hadikusuma dam Hilman. Hukum Pidana

Adat. Bandung: Alumni, 1984.

Hamzah, Andi. Sistem Pidana dan

Pemidanaan Indonesia dari Retribusi

ke Reformasi. Cetakan Ke-1. Jakarta:

Pradnya Paramita, 1986.

Maulana dan Slamet. Perundang-undangan

Majapahit. Jakarta: Bhatara, 1967.

Muladi dan Barda Nawawi Arief. TeoriTeori dan Kebijakan Pidana. Bandung: Alumni, 1998.

Ost, S. Child Pornography and Sexual Grooming: Legal and Societal
Responses. Cambridge: Cambridge University Press, 2009.

Sudarto. Hukum dan Hukum Pidana. Bandung: Alumni, 1983.

Taylor M. and E. Quayle. Child Pornography: An Internet Crime. London: Routledge, 2003.

\section{Jurnal}

Cattaneo, Cristina dkk. "Can facial proportions taken from images be of use for ageing in cases of suspected child pornography? A pilot study". Int J Legal Med Vol. 126, Issue 1, (January 2012): 139.

Lillie, Jonathan James McCradie. "Cyberporn, Sexuality and The Net Apparatus". Convergence Vol. 10, Issue 1, (March 2004): 47.

Martellozzo, Elena dan Hellen Taylor. "Cycle of Abuse". Index on Cencorship Vol. 38, Issue 1, (March 2009): 117.

Weinberg, Martin S. dkk. "Pornography, Normalization, and Empowerment". Arch Sex Behav Vol. 39, Issue 6, (December 2010): 1389. 